18.

\title{
PRILOZI POLITIČKOJ, KULTURNOJ \\ I INTELEKTUALNOJ HISTORIJI \\ SPLITA U DOBA BANOVINE \\ HRVATSKE (1939. - 1941.)
}

\section{Matko Globačnik}

UDK: 930.85(497.5 Split)“1939/1941“

Izvorni znanstveni članak

Sažetak: Sporazum Cvetković - Maček iz kolovoza 1939. uspostavio je autonomnu Banovinu Hrvatsku unutar Kraljevine Jugoslavije. Nove političke okolnosti uvjetovale su drugačiji položaj Splita u državi te drugačiji odnos snaga između i unutar političkih stranaka snažnije prisutnih u gradu, što se jasno vidjelo u sukobu hrvatskog (nacionalnog) i jugoslavenskog identiteta te jačanju novih tendencija među srpskim stanovništvom u splitskome zaleđu. Istodobno izbijanje Drugoga svjetskoga rata u Europi donijelo je ekonomske teškoće nerazvijenome dalmatinskome središtu, što se pokazalo kao plodno tlo za djelovanje lokalnih komunista. Takve su se političke konstelacije odražavale na djelovanje splitskih umjetnika, intelektualaca i kulturnih radnika, kojih je u gradu bio nemali broj. Split je unatoč teškim prilikama pokazivao znakove razvoja, pogotovo u osnivanju novih udruženja, kulturnih institucija te u izgradnji novih građevina.

Ključne riječi: Split, Banovina Hrvatska, Kraljevina Jugoslavija, politička historija, kulturna historija, intelektualci

\section{UvoD}

T ratko razdoblje u kojemu je Split bio unutar Banovine Hrvatske u historiografiji se uglavnom obrađivao kao dio tematski opširnijih pregleda, poput povijesti grada ili Gregije u čitavom međuratnom periodu. ${ }^{1}$ Međutim, zbog specifičnih okolnosti unutar i izvan Kraljevine Jugoslavije od kolovoza 1939. do travnja 1941., prilike u gradu bile su poprilično drugačije od onih koje su obilježavale prethodna razdoblja, što je zasebna tema

Usporedi Aleksandar JAKIR, Dalmatien zwischen den Weltkriegen. Agrarische und urbane Lebenswelt und das Scheitern der jugoslawischen Integration, München 1999., 427-443; Zdravka Jelaska Marijan, Grad i ljudi: Split 1918.-1941., Zagreb 2009., 140-142. 
kojoj se ipak posvetio manji broj radova. ${ }^{2}$ Dinamičan politički, kulturni i intelektualni život Splita neposredno prije Drugoga svjetskoga rata još nije doživio svoju primjerenu valorizaciju. Stoga je cilj ovoga rada prikazati glavne crte političkog i kulturnog stanja Splita te naznačiti tok intelektualnog stvaralaštva u gradu u tome vremenu. U prikazu političkog stanja fokus je na konstelacijama unutar i između stranaka snažnije prisutnih u gradu, što se istražuje prvenstveno kroz tadašnji tisak, a unutarnjopolitičko stanje stavlja se u kontekst zbivanja u Jugoslaviji i svijetu. U okviru takvih političkih zbivanja ocrtava se onovremeni kulturni razvoj i intelektualno stvaralaštvo u Splitu, koje još nije detaljnije istraženo. Kratki pregled djelatnosti istaknutih splitskih umjetnika i intelektualaca te prikaz stvaranja novih kulturnih institucija i revitaliziranja starih na temelju arhivske građe i tiska mali je prilog toj temi.

\section{PolitičKe KONSTELACIJE}

Topli se kolovoz te sudbonosne 1939. godine primicao kraju, a Split je bio pun stranih turista, koji su se posljednjih mjeseci slijevali u taj mediteranski grad. ${ }^{3}$ Ipak, stalne političke mijene, koje kroničari ne propuštaju suhoparno bilježiti, nikada ne prestaju pa je i tada to politički uvijek temperamentno i šareno „velo misto“ živjelo u iščekivanju konačnog sporazuma glavnih predstavnika Hrvata i Srba u Jugoslaviji. ${ }^{4}$ Kada je Sporazum 26. kolovoza službeno postignut između predsjednika Hrvatske seljačke stranke (HSS) Vladka Mačeka i premijera Dragiše Cvetkovića iz Jugoslavenske radikalne zajednice (JRZ) uspostavljajući Banovinu Hrvatsku, to je bila prilika za još jedno razmatranje i (re)interpretaciju nedavne povijesti političkih afilijacija raznih slojeva splitskog građanstva. ${ }^{5}$ Ključni je problem bila konsolidacija nacionalnog tj. hrvatskog i jugoslavenskog identiteta. To nije bila hrvatska ili splitska posebnost, nego zapravo jedno od najvažnijih i gotovo nerazrješivih pitanja za sve narode u Kraljevini Jugoslaviji, ali je u Splitu to pitanje, zbog položaja i povijesti grada, imalo svoje specifičnosti.

$S$ jedne strane, uspostava Banovine Hrvatske bila je za mnoge pristaše Sporazuma prilika da se jače naglasi centralna uloga Splita u hrvatskoj kulturi i nacionalnom identitetu. $\mathrm{Hr}$ vatske su trobojnice zalepršale u gradu i na Marjanu, vršila su se preimenovanja kulturnih institucija, istaknuti su intelektualci držali predavanja, poput ekonomista Rudolfa Bićanića o zainteresiranosti Zagreba za ekonomske potrebe Splita ili povjesničara Josipa Nagya o nerazdruživoj povezanosti Dalmacije i Hrvatske, koja je u Banovini Hrvatskoj doživjela

2 Kao jedan od rijetkih takvih radova usp. Fikreta Jelić Butić, „Banovina Hrvatska. Političke prilike na području Ispostave banske vlasti u Splitu 1939.-40. godine“, Slobodna Dalmacija (Split; dalje: SD), br. 14313 - br. 14330, 6. -23. 10. 1990.

3 „Treba regulirati ljetne večernje priredbe“, Novo doba (Split; dalje: $N D$ ), br. 179, 2. 8. 1939., 5; „Veliki priliv stranaca u Splitu“, ND, br. 179, 2. 8. 1939., 6.

4 „Pripremanje sporazuma sa Hrvatima glavni zadatak vlade g. Dragiše Cvetkovića“, ND, br. 32, 7. 2. 1939., 1.

5 „Prihvaćen predlog o rješenju hrvatskog pitanja“, $N D$, br. 199, 25. 8. 1939., 1; „Prva vlada narodnog sporazuma“, Hrvatski glasnik (Split; dalje: $H G$ ), br. 200, 26. 8. 1939., 2; „Nova vlada sporazuma“, ND, br. 200, 26. 8. 1939., 1; „Historijske odluke o izvršenju sporazuma“, ND, br. 200, 26. 8. 1939., 2. 


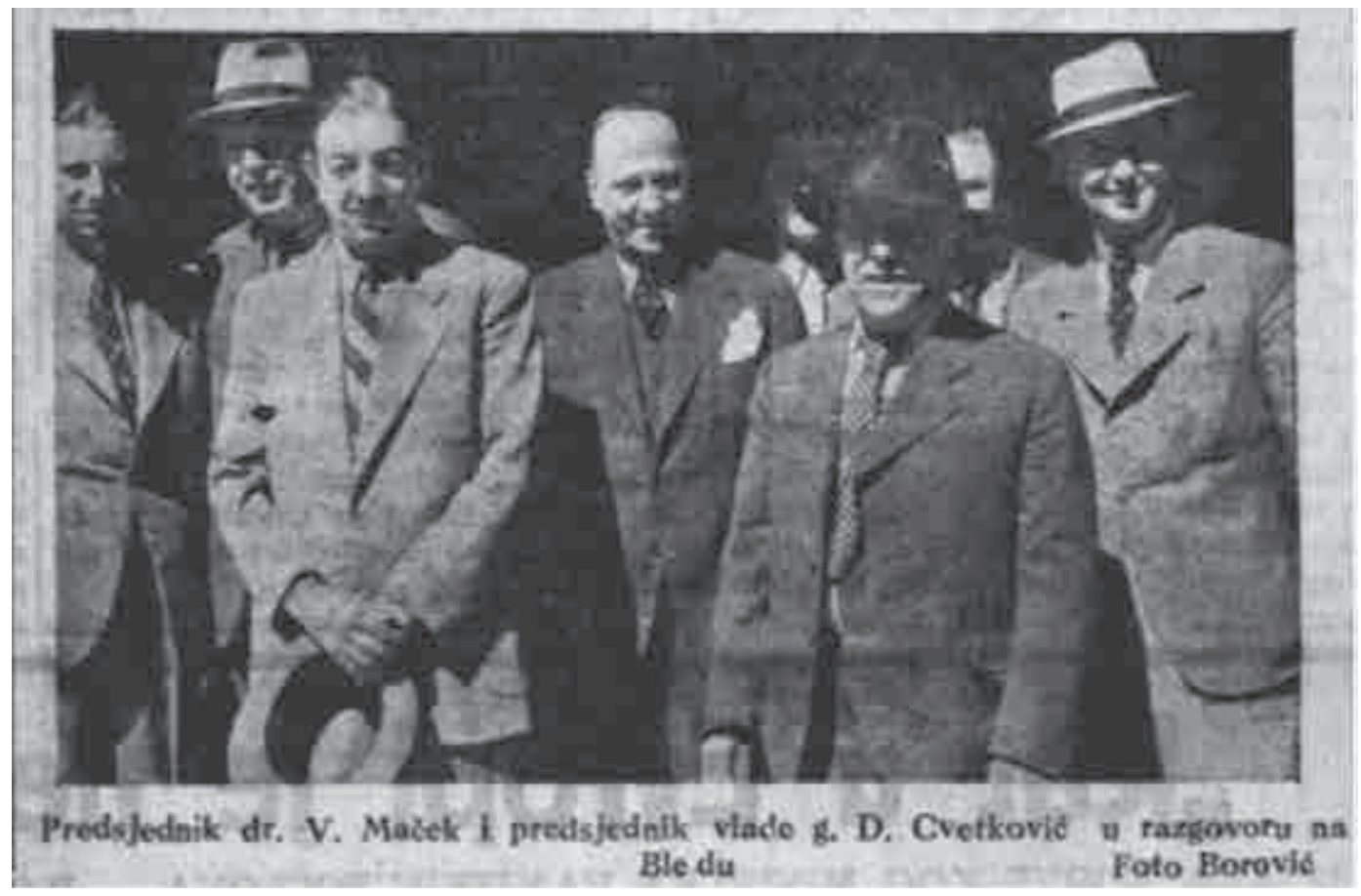

Sl. 1. Ministri nove vlade u objektivu splitskog fotografa: „Pred hotelom 'Toplice' sakupili su se svi ministri i tu su ih fotografirali brojni fotografi i novinski fotoreporteri. Među ostalima snimao je i splitski fotograf g. Ante Borović."

„prirodan završetak procesa“. ${ }^{6}$ Takav je determinizam čitavu hrvatsku prošlost interpretirao kao borbu dviju struja u kojoj je „narodna“ pobijedila kroz konačno „sjedinjenje Dalmatinske sa Panonskom Hrvatskom“, što se često provlačilo kroz splitski tisak kao jedno od glavnih postignuća Sporazuma. ${ }^{7}$ Prvi Božić nakon uspostave Banovine Hrvatske slavio se „u slobodi (...) jer je svanula zora“ koje nije bilo kada je zemljom „vladala bol“. ${ }^{8}$

Istodobno je počelo oštrije obračunavanje s poraženim političkim protivnicima i slobodnije formiranje hrvatskoga martirologija. Šuškalo se o mučenjima i zlostavljanjima na policiji za vrijeme „prošlih režima“, a slučaj Milana Šufflaya uskrsnuo je kroz obnovu procesa njegovim ubojicama. ${ }^{9}$ Kako se u Splitu formirala Ispostava Banske vlasti, s primjetnim se zadovoljstvom opširno izvještavalo o smjeni dotadašnjih lokalnih vlasti i činovnika, kojima se i javno prijetilo jer su „zasnovali svu svoju karijeru“ na sabotaži i uroti „proti hrvatskog naroda“. ${ }^{10}$ Dok je nekima sunce zalazilo, drugi su se nadmetali da u novim politič-

6 „Hrvatske zastave zalepršale na Marjanu“, ND, br. 209, 5. 9. 1939., 5; „Stara splitska Čitaonica povratila je društvu svoje hrvatsko ime“, ND, br. 243, 9. 10. 1939., 5; „Konferencija dra Rudolfa Bićanića“, ND, br. 264, 30. 10. 1939., 6; „Dalmacija i Hrvatska“, ND, br. 270, 5. 11. 1939., 7.

7 Rudolf Pederin, „Osvrt na sporazum“, ND, br. 230, 20. 1. 1940., 2.

8 F. D. Marušić, „Novi Božić u Slobodnoj Hrvatskoj“, ND, br. 319, 25. 12. 1939., 2.

9 „Mučenja na policiji“, $N D$, br. 234, 30. 9. 1939., 6; „Istraga o umorstvu dra Šufflaya“, ND, br. 243, 9. 10. 1939., 2; „Razotkriva se tajna umorstva pok. dra Šufflaya“, ND, br. 247, 13. 10. 1939., 2.

10 Vidi npr. „Promjene u činovništvu Dalmatinske Hrvatske“, ND, br. 232, 28. 9. 1939., 3; „Opomena onima, koji je trebaju!“, $H G$, br. 202, 29. 8. 1939., 6. 
kim okolnostima baš njih jače obasja. Tako su se u veljači 1940. jedina dva dnevna lista u Splitu, nezavisno Novo doba i službeno glasilo HSS-a Hrvatski glasnik, prepirala oko toga tko je štitio lokalne činovnike za vrijeme diktature i promovirao „nehrvatska (...) sokolska“ društva u Splitu. Dok je Hrvatski glasnik napadao Novo doba da zbog svoje probitačnosti štiti gradonačelnika Stjepana Spalatina, dotle je Novo doba optuživalo Hrvatski glasnik da promovira bivšeg gradonačelnika i nekadašnjeg bana Ivu Tartagliu koji je sve do nedavno zastupao kraljevu diktaturu i unitarizam i koji je oštro govorio protiv HSS-a da bi tek nakon Sporazuma „okrenuo barjak“. ${ }^{11}$ Rasprava je nastavljena u kolovozu iste godine u obliku razmirice dvaju istaknutih suradnika tih dnevnih listova, odvjetnika Rudolfa Pederina i problematičnog HSS-ovca Paška Kaliterne. Oni su se međusobno optuživali oko toga tko je bio pravi branitelj Vladka Mačeka, njegove stranke i hrvatskog seljaštva općenito u vrijeme kada su oni bili u nemilosti režima. Kaliterni to nije bio prvi sukob. Osim što je izazivao nesuglasice s vođom Samostalne demokratske stranke (SDS) u Splitu Ljubom Leontićem, i u samome splitskome HSS-u stvorio je rascjep već u listopadu 1939. godine pa se čitavo članstvo podijelilo na dvije struje, jednu koja je podržavala Josipa Berkovića i drugu koja je podržavala Kaliternu. ${ }^{12}$ Sve je to jasno pokazalo slabost vodstva HSS-a da u Splitu disciplinira vlastite redove (u koje su se uvukli radikalni elementi poput ustaša i komunista) i homogenizira različita mišljenja sklona njezinoj politici. ${ }^{13}$

Vodstvo Banovine Hrvatske ipak je pokušavalo biti kohezijska snaga u okupljanju hrvatskih nacionalnih strujanja te je nakon Sporazuma smatralo HSS pobjednikom i vrhuncem hrvatskog političkog razvoja. Maček je imao neprijepornu ulogu - prvi i jedini rođendan „mudrog Vođe hrvatskog naroda“ i nasljednika „velikog Učitelja blagopokojnog Stjepana Radića“ proglašen je „danom slobode“ te se svečano slavio u Splitu „u obnovljenoj hrvatskoj domovini “. ${ }^{14}$ Stranka je kao isključivi pretendent na narodno vodstvo u svoju tradiciju uklopila ključne nacionalne političke ideologije iz prošlosti kako bi eliminirala političke protivnike. Tako je stranačka mladež redovito organizirala zadušnice za utemeljitelje pravaštva, Antu Starčevića i Eugena Kvaternika, slaveći „krvlju otkupljenu Hrvatsku“ i pozivajući na složno izgrađivanje države protiv onih koji „među nama (...) svojim radom odigravaju izdajničku ulogu“, tj. protiv malobrojnih ustaša kojima su na čelu stajali odvjetnici Ivo Cuzzi i Edo Bulat. ${ }^{15}$ U gradu snažan odjek prve godišnjice smrti vrlo respektiranog

11 „Izjava dra Spalatina“, HG, br. 39, 16. 2. 1940., 6; „Još oko jedne izjave“, ND, br. 40, 17. 2. 1940., 6; „Uzaludno izmotavanje“, $H G$, br. 41, 19. 2. 1940., 6; „Hrvatski Glasnik i Novo Doba“, ND, br. 42, 20. 2. 1940., 6.

12 F. Jelić Butić, „Banovina Hrvatska (...): Sukob u splitskom HSS-u“, SD, br. 14323, 16. 10. 1990., 27.

13 Rudolf Pederin, „Moj drugi odgovor Pašku Kaliterni“, ND, br. 198, 22. 8. 1940., 6; „Povodom jedne Batrakomiomahije“, Narodni list (Split; dalje: $N L$ ), br. 33, 22. 8. 1940., 1; „Izmirenje gg. P. Kaliterne i A. Matijevića“, Nova tribuna (Šibenik; dalje: NT), br. 629, 5. 4. 1940., 3; „Sukob između HSS i Hrvatskog Glasnika“, NT, br. 629, 5.4. 1940., 3; „Frankovci i komunisti i HSS“, NT, br. 660, 27. 11. 1940., 3; A. JAKIR, Dalmatien zwischen den Weltkriegen, 440 .

14 „Hrvatski Split slavi 20 i 21 srpnja svoga Vođu“, ND, br. 167, 17. 7. 1940., 4; Paško Kaliterna, „Dan hrvatske slobode“, $H G$, br. 170, 20. 7. 1940., 1.

15 „Za dra Eug. Kvaternika“, ND, br. 248, 14. 10. 1939.; „Zadušnice i komemoracija za E. Kvaternika“, ND, br. 254 , 20. 10. 1939., 6; „Zadušnice za A. Starčevića“, ND, br. 53, 4. 3. 1940., 6; A. JAKIr, Dalmatien zwischen den Weltkriegen, 440; F. Jelić Butić, „Banovina Hrvatska (...): Povjerljivi izvještaji“, SD, br. 14314, 7. 10. 1990., 25. 
splitskog političara Ante Trumbića pokazao je politiku sjećanja HSS-a, tako da je Trumbićev udio u stvaranju Kraljevstva Srba, Hrvata i Slovenaca bio gotovo potpuno prekrit isticanjem njegove borbe za slobodu i jedinstvo Hrvata te njegovim kasnijim savezništvom s Radićem i Mačekom. ${ }^{16}$

Međutim, takvo je političko usmjerenje došlo u konflikt s prošlom realnošću i političkom sadašnjošću te širim jugoslavenskim identitetom. Unatoč snažnim riječima o slobodi i domoljublju, Banovina Hrvatska još je uvijek, naravno, bila dio Kraljevine Jugoslavije, a time je dijelila njenu povijest i probleme. Novine su izvještavale o godišnjicama smrti pokojnog kralja Aleksandra Karađorđevića, a datumi ulaska srpske vojske u Split (20. 11. 1918.) i ujedinjenja (1. 12. 1918.) i dalje su se slavili. ${ }^{17}$ Paradoksalna je bila koegzistencija takvih konfliktnih politika sjećanja. One su istodobno slavile mučeničke borce potpuno suprotstavljenih orijentacija poput Radića, Šufflaya i Aleksandra, ujedinjenje i oslobođenje, slobodnu Hrvatsku i slobodnu Jugoslaviju. Kroz splitski je tisak vidljivo da je HSS-ova strategija bila ukloniti ta proturječja teleološkom interpretacijom povijesnih događaja, kao dio trnovitog, ali ipak napredujućeg procesa koji se kretao prema konačnoj svrsi, potpunom rješenju hrvatskog pitanja, kojim bi Hrvatska postala jamac stabilnosti Jugoslavije. Tako je ujedinjenje 1. 12. 1918. imalo svoj smisao jedino utoliko što je bilo prijelazni stupanj prema uspostavi Banovine Hrvatske, ali je samo po sebi tadašnje stanje bilo neodrživo. Po banu Ivanu Šubašiću, tek je Sporazum omogućio da Hrvatska stoji na braniku Jugoslavije jednako kao što je i Jugoslavija Sporazumom postala stvarni jamac sigurnosti Hrvatske. ${ }^{18}$ Ipak, takva interpretacija nije mogla izbrisati desetljeća sukoba između pobornika različitih političkih orijentacija, što se obilno koristilo u javnim polemikama radi diskreditiranja protivnika. Najbolja je ilustracija konfliktne politike sjećanja članak u Novome dobu o istrazi ubojstva Milana Šufflaya, pokraj kojega je bio članak pun pijeteta o kralju Aleksandru, najodgovornijem za Šufflayevo ubojstvo. ${ }^{19}$

Pokušaj tendencioznog korištenja i sintetiziranja različitih političkih ideologija iz prošlosti radi legitimacije nikako nije bio karakterističan samo za HSS. Ako su listovi nakloni toj stranci ponekad i dolazili u konflikt, za Narodni list, službeno glasilo opozicijske Jugoslavenske nacionalne stranke (JNS) za primorske krajeve, čiji je prvi broj izašao u studenom 1939. u Splitu, može se reći da je stalno bilo primorano polemizirati s novinama iz cijele Jugoslavije. ${ }^{20}$ Kao nepokolebani jugoslavenski nacionalisti, unatoč rasulu svoje stranke, urednik lista i bivši ministar Budislav Grga Anđelinović te njegovi suradnici, poput Uroša

16 „Dr Ante Trumbić“, ND, br. 283, 18. 11. 1939., 1; „Split se je dostojno odužio uspomeni svog prvoborca za slobodu Hrvatske“, $H G$, br. 271, 20. 11. 1939., 6.

17 „Pomen blagopokojnom Kralju Aleksandru“, ND, br. 243, 9. 10. 1939., 2; „Proslava 1 prosinca“, ND, br. $285,2.12$. 1940., 6; „Proslava dana ulaska srpske vojske u Split“, NT, br. 611, 24. 11. 1939., 3; „Split za Kraljem Mučenikom“, NT, br. 655, 18. 10. 1940., 3 .

18 „1 prosinca“, ND, br. 284, 30. 11. 1940., 2.

19 „Istraga o umorstvu dra Šufflaya“, $N D$, br. 243, 9. 10. 1939., 2; „Pomen blagopokojnom Kralju Aleksandru“, $N D$, br. 243, 9. 10. 1939., 2.

20 Usporedi npr. „Polemika“, NL, br. 2, 7. 11. 1939., 7; „Polemika sa 'Hrvat. Glasnikom”“, NL, br. 4, 23. 11. 1939., 3. Općenito o JNS u Banovini Hrvatskoj vidi Krešimir Regan, „Djelovanje Jugoslavenske nacionalne stranke u Banovini Hrvatskoj 1939-1941.“, Kolo, 17/2007., br. 4, 108-125. 
Desnice i Jovana Banjanina, našli su se na udaru strana koje su u njihovim stavovima vidjeli nastavak politike provođene prije Sporazuma. ${ }^{21}$ Da bi legitimirali svoje političko stajalište nasuprot HSS-u i tzv. Savskoj grupi JNS-a, koja je odbijala slijediti federalističku politiku središnjice u Beogradu, Anđelinovićevi pristaše pozivali su se na „misli velikih slovinskih, dalmatinskih i ilirskih preporoditelja“, pri čemu se tu mislilo na predstavnike najrazličitijih političkih usmjerenja. Tako su ruku pod ruku svrstani Starčević i Kvaternik, Franjo Rački i Josip Juraj Strossmayer, Ljudevit Gaj i Tomislav Maretić, ne samo protiv „gotskih rasista“ kao što su kojekakvi „Šegvići, Budaci, Šimraci i Bućevi“, nego prvenstveno protiv „germanske Austrije i protuhrvatske Mađarske“ kojima su služili Isidor Kršnjavi i Stjepan Sarkotić, pri čemu je ovaj potonji bio posebno ocrnjen kao onaj koji je strijeljao jugoslavenske dobrovoljce, ratnike za slobodu. ${ }^{22}$ Vrhunac takvog shvaćanja bilo je harmoniziranje političkih pogleda Stjepana Radića i kralja Aleksandra u njihovoj glavnoj brizi za „državu i narod“. Pritom nije spomenuto da su njihovi pogledi na uređenje države i identitet naroda bili suprotstavljeni, kao i da je politika jednoga bila smrtna presuda drugome. ${ }^{23}$

Odmah u uvodniku prvoga broja Narodnoga lista naglašena su temeljna politička uvjerenja kruga oko Anđelinovića. Po njima su Srbi, Hrvati i Slovenci (tim redom) jedan, sudbinski povezan narod. Ako je za HSS stanje kakvo je bilo neposredno nakon ujedinjenja imalo smisao tek kada ga se promatralo kao prijelazni stupanj prema rješenju hrvatskog pitanja koje ni Sporazumom nije bilo potpuno, za JNS iz bivše Primorske banovine je uspostavljanje Banovine Hrvatske bilo neodrživo ako ujedno nije pretpostavljalo „integralno riješenje (sic!) pitanja, tj. punu državnu reformu“, jer je u ovome stanju Banovina Hrvatska „corpus separatum“ koji vraća državu na „duh plemenske isključivosti“ “. ${ }^{24}$ Uroš Desnica opravdavao je integralno jugoslavenstvo povijesnim čimbenicima. Južni su Slaveni „dali prvi i najsnažniji impuls svjetskim događajima iz godina 1912 do 1919 “, požrtvovnom su borbom stvorili svoju prirodnu državu i ostvarili slobodu, nakon čega je uslijedilo dvadeset godina lutanja u kojemu je nastradalo „duhovno jedinstvo“. Iako je isprva bio suzdržan prema Sporazumu, Desnica je upozorio da je pobjednička Srbija imala „moralnu veličinu“ odbiti Veliku Srbiju jer nije htjela napustiti druga dva „plemena“, da bi se sada „nekom sadističkom nasladom“ uložili „svi napori za što potpunije odvajanje u svim oblastima javnog, društvenog i kulturnog života“, što se ogleda u mijenjanju „narodnoga“ imena „plemenskim“, stvaranju

$\overline{21}$ O Anđelinoviću, Desnici i Banjaninu usporedi: Anđelka StipčEvić-Despotović, „Budislav Grga Andjelinović“, Hrvatski biografski leksikon (dalje: $H B L$ ), sv. 1, Zagreb 1983., 166; Mira Gumhalter, „Jovan Banjanin“, $H B L$, sv. 1, 427-428; Drago Roksandić, „Dr. Uroš Desnica 1918. - 1921.: životopisne nedoumice na raskrižju epoha“, Spalatumque dedit ortum. Zbornik povodom desete godišnjice Odsjeka za povijest Filozofskog fakulteta u Splitu (ur. Ivan Basić i Marko Rimac), Split 2014., 499-507; Dragan BAKıć, „Prilog za biografiju: politička karijera Uroša Desnice u vremenu iskušenja (1919-1941)“, Vladan Desnica i Split 1920. - 1945. Zbornik radova sa znanstvenog skupa Desničinih susreta 2014. (ur. Drago Roksandić i Ivana Cvijović Javorina), Zagreb 2015., 235-257; Stjepan Matković, „Senatori iz Splita: suočavanje s krizom Jugoslavije i jugoslavenstva“, isto, 307-330.

22 „Svojim putem“, $N L$, br. 1, 1. 11. 1939., 1; „Nekrolozi general-obrstu barunu Sarkotiću“, NL, br. 1, 1. 11. 1939. 4; „Kvaternikova proslava“, $N L$, br. 1, 1. 11. 1939., 6; Niko Bartulović, „Borba protiv hrvatstva“, $N L$, br. 5, 1. 2. 1940., 2.

23 „Kralj i narod“, NL, br. 35, 8. 9. 1940., 1.

24 "Svojim putem“, $N L$, br. 1, 1. 11. 1939., 1; Munib Osmanagić, „Između dobra i zla“, NL, br. 6, 7. 12. 1939., 4. Vidi i „Dan ujedinjenja“, $N L$, br. 5, 30. 11. 1939., 1. 


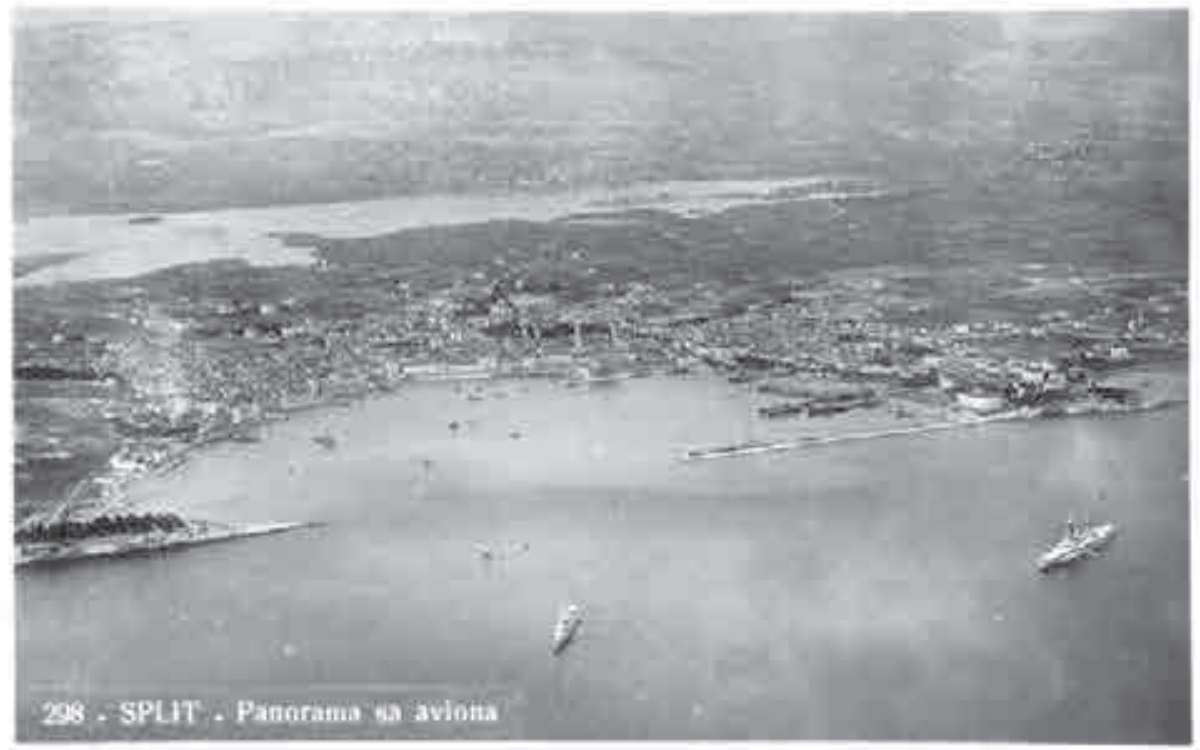

Sl. 2. Split 1930 -ih godina

„novog hrvatskog književnog jezika“ i u gotskoj teoriji o podrijetlu Hrvata. Unatoč svemu, Desnica smatra da su Srbi, Hrvati i Slovenci doživjeli u novoj državi „neizmjerno mnogo više dobra nego zla“. 25

Anđelinovićevi pristaše znali su dobro uočiti boljke prevladavajuće političke paradigme u Splitu za vrijeme Banovine Hrvatske, poput gospodarske zaostalosti Dalmacije, Mačekova kulta, nacionalne isključivosti, ograničavanja slobode govora, selektivne politike sjećanja, lešinarenja nad niskorangiranim činovnicima zbog njihova političkog opredjeljenja u prošlosti i uvlačenja radikalne desnice u redove HSS-a. ${ }^{26}$ Međutim, oni su i sami bili preopterećeni sličnim djelima iz svoje prošlosti poput otvorenog podržavanja diktature i svega što ju je pratilo (nasilje, cenzura i politički pritisci), pa se čak nisu niti distancirali od njih, nego su do samoga kraja branili orjunašku politiku i politički motivirana ubojstva. ${ }^{27} \mathrm{Za}$ gospodarsko stanje Dalmacije i Splita oni su bili puno odgovorniji od HSS-a, njegovali su kult neprežaljenoga „Kralja Mučenika“, a hrvatski i srpski nacionalizam nadomjestili su jednako isključivim jugoslavenskim koji u sebi nije mogao zadovoljavajuće izmiriti jugoslavenski i hrvatski identitet. S obzirom da su iz takve pozicije s gorkim cinizmom kritizirali svaki po-

25 Uroš Desnica, „Osvrt na prošlost - pouka za budućnost“, $N L$, br. 1, 1. 11. 1939., 1; Uroš DesnicA, „Razmišljanja“, NL, br. 15, 18. 4. 1940., 2.

26 „Pismo iz Zagreba“, $N L$, br. 2, 7. 11. 1939., 4; „Činovnici u novim prilikama“, $N L$, br. 2, 7. 11. 1939., 4; „Problem Primorske oblasti“, $N L$, br. 3, 16. 11. 1939., 1; „Dux“, $N L$, br. 4, 23. 11. 1939., 1; „Jednu je godinu u grobu“, $N L$, br. 4, 23. 11. 1939., 3; „Pod maskom hrvatstva“, NL, br. 4, 23. 11. 1939., 5; „Skrajnosti“, NL, br. 7, 14. 12. 1939., 1; „Falsifikati“, $N L$, br. 8, 21. 12. 1939., 4; „Iz hrvatske martirologije“, NL, br. 13, 4. 4. 1940., 3; „Hrvatski nacionalisti“, $N L$, br. 49, 12. 12. 1940., 1; „Rasna teorija i nacionalna politika“, $N L$, br. 51, 24. 11. 1940., 2; „Sloboda mišljenja treba u Hrvatskoj uvijek biti zajamčena“, $N L$, br. 5, 6. 2. 1941., 2.

27 „Činjenice...“, $N L$, br. 11, 21. 3. 1940., 1; „Iz nedavne prošlosti...“, $N L$, br. 19, 16. 5. 1940., 3; „Šufflay...“, $N L$, br. 8, 27. 2. 1941., 2 . 
tez koji je vodio nacionalnoj afirmaciji na području kulture - poput promjene imena JAZU u HAZU, pokretanja Hrvatske enciklopedije i oslobađanja hrvatskog jezika od unitarističke politike - samo su si učvrstili epitet „mrzitelja hrvatstva“. ${ }^{28}$ Nije stoga čudno da na prigovore njihovoj poraženoj politici nisu imali djelotvornog ili barem uvjerljivog odgovora. ${ }^{29}$

Politika dviju suprotstavljenih splitskih stranaka, HSS i JNS, u Splitu se jasno manifestirala u svakodnevici. Njihova se propaganda ostvarivala kroz stranačke organizacije, predavanja, skupove i javne manifestacije, pri čemu su plesovi bili karakteristični za HSS, a sokolska društva i dalje su igrala važnu ulogu za JNS. ${ }^{30}$ Kako su obje strane uključivale iste velikane u svoju politiku sjećanja, često je dolazilo do polemika, pa i brojnih ispada na ulicama grada u raznim svečanim prilikama, najviše na štetu oslabljene JNS. ${ }^{31}$

Ostale političke stranke poput JRZ-a i SDS-a nisu bile jače prisutne u samome Splitu. JRZ prema vlastitu priznanju „ne pokazuje nikakve znakove života, kako u Splitu tako i u ostalim d[i]jelovima bivše Primorske banovine“, a mjesna organizacija stranke „likvidirana“ je odmah po uspostavi Banovine Hrvatske jer se tražilo povlačenje dotadašnjih hrvatskih političara poput Vlade Matošića, s obzirom da su otežavali odnose s HSS-om. ${ }^{32}$ Matošić je bio pripadnik Stojadinovićeve frakcije u JRZ-u koja je nakon „izbacivanja“ iz Splita očitovala velikosrpske tendencije u splitskome zaleđu kroz različita društva poput „Krajine udruženja za kulturno i privredno podizanje naroda" te sličnih organizacija. Njihova traženja da se po različitim kriterijima proglašeni srpski krajevi trebaju izdvojiti iz Banovine Hrvatske dobili su potporu od Stojadinovićeve frakcije u JRZ-u i tzv. Savske grupe u JNSu. ${ }^{33} \mathrm{Na}$ općinskim izborima u svibnju 1940. godine, na kojima JNS nije htio sudjelovati jer JRZ sa Cvetkovićem na čelu i SDS podupiru HSS-ovu politiku koja „daje ovim izborima čisti totalitarni partijski karakter", Seljačko-demokratska koalicija (SDK) uspjela je odnijeti pobjedu u većini općina, a SDS je osvojio najveći broj glasova banovinskih Srba. ${ }^{34} \mathrm{Ali}$ unatoč snažnoj potpori hrvatskog banovinskog tiska SDS-u, simpatizeri velikosrpske politike svoju su ilegalnu djelatnost zamaskirali u tzv. srpske nezavisne liste koje su u kninskoj općini uspjele izboriti pobjedu, zbog čega je brzo došlo da raznih incidenata poput progla-

28 „Borba protiv jugoslovenskih imena“, $N L$, br. 7, 14. 12. 1939., 3; „Akademici su učinili svoje, a budućnost i prošlost neka govore svoju“, $N L$, br. 7, 14. 12. 1939., 8; „Pothvat jedne enciklopedije u Zagrebu“, NL, br. 1, 18. 1. 1940., 8; „Čišćenje hrvatskog jezika“, $N L$, br. 17, 2. 5. 1940., 8; „Novi govor o hrvatskoj kulturi“, $N L$, br. 26, 4. 7. 1940., 4; „Ne mrzimo sve što je hrvatsko!“, $N L$, br. 3, 23. 1. 1940., 1.

29 „Autokritika“, $N L$, br. 5, 1. 2. 1940., 1; „Još nešto o jednom od onih, koji mijenjaju ime Akademije“, $N L$, br. 21, 30. 5. 1940., 8; „Obljetnica smrti Kralja - mučenika“, NL, br. 40, 10. 10. 1940., 1.

30 Usporedi npr.: „Veliki ples Hrvatske seljačke stranke u Splitu“, ND, br. 17, 22. 1. 1940., 6; „Sokolski vjesnik. Za 'Jugoslovenski savez“", $N L$, br. 1, 1. 11. 1939., 1; „Život je rekao svoju riječ, a jugoslovensko sokolstvo će je razumjeti“, $N L$, br. 7, 14. 12. 1939., 3; „Komemoracije Kraljeve pogibije“, NT, br. 605, 13. 10. 1939., 3. O „Jugoslavenskom sokolu“vidi A. JAKIR, Dalmatien zwischen den Weltkriegen, 370-381.

31 „Sokolski vjesnik. Krivi su jer proslavljaju dan Zrinskog i Frankopana“, NL, br. 17, 2. 5. 1940., 5; „Split“, NL, br. 46, 21. 11. 1940., 3 .

32 „Politički život u Splitu“, NT, br. 606, 20. 10. 1939., 3. O JRZ u Banovini Hrvatskoj vidi Krešimir REgan, „Djelovanje Jugoslavenske radikalne zajednice u doba Banovine Hrvatske (1939-1941)“, Studia lexicographica, 1/2007., br. $1,217-254$.

33 Isto, 220-225; Krešimir Regan, „Političko djelovanje Krajine u Banovini Hrvatskoj“, Historijski zbornik, 60/2007., 179-213; „Oko akcije društva 'Krajina'“, NT, br. 620, 26. 1. 1940., 4.

34 Isto, 202; „Saopćenje banovinskog odbora JNS“, ND, br. 103, 3. 5. 1940., 6. 
šavanja tih krajeva srpskima. ${ }^{35}$ Takav je razvoj situacije imao odjeka u Splitu u vidu međustranačkih borbi. Dok je tisak privržen SDK-u snažno osuđivao tendencije poput onih u kninskome kraju, Anđelinovićev je krug u ime JNS-a i prije toga sa zadovoljstvom konstatirao da se takve pojave mogu riješiti samo povratkom jugoslavenskom nacionalizmu. ${ }^{36}$

Svoju je ilegalnu aktivnost u Splitu također posredno uspjela ostvariti Komunistička partija Jugoslavije (KPJ), kroz Udruženje radničkih sindikata (URS), koje je bilo oštro suprotstavljeno splitskoj Radničkoj komori, inače potpornom stupu politike Banovine Hrvatske prema radnicima. ${ }^{37}$ Naime, komunističko je vodstvo, na čelu s Josipom Brozom Titom, pod utjecajem Kominterne Sporazum ocijenilo kao ustupak srpske buržoazije hrvatskoj, kako bi ju učinilo saveznikom u borbi protiv „radnog narod“" $\mathrm{i}$ čitavu Jugoslaviju gurnuo u „imperijalistički“ rat na strani „engleskih i francuskih potpaljivača rata“. Zbog toga je bilo potrebno što više učvrstiti KPJ i boriti se „odozdo“ protiv reakcionarnih, „buržoaskih tzv. demokratskih partija “. ${ }^{38}$ Komunistički vođe u Dalmaciji Vicko Jelaska, Ivo Baljkas i Ivo Marić nisu se slagali s tom politikom pa su nastupile frakcionaške borbe u kojima je vodstvo pridobio Vicko Krstulović. U međuvremenu je URS organizirao nekoliko više ili manje uspješnih štrajkova u gradu tijekom postojanja Banovine Hrvatske. ${ }^{39}$ Zasigurno najpoznatiji događaj u režiji komunista odigrao se 17. prosinca 1939., kada je u središtu Splita održan prosvjed protiv skupoće s otprilike tisuću sudionika. On je ubrzo prerastao u oružani sukob policije i demonstranata, pri čemu je poginuo komunist Vicko Buljanović. To je izazvalo štrajkove solidarnosti i daljnje sukobe koji su se smirili nakon nekoliko dana. Štrajkovi su održavani i sljedeće godine, dok URS nije zabranjen 31. prosinca $1940 .{ }^{40}$ Jedan od glavnih čimbenika nezadovoljstva nižih slojeva zasigurno je bila sve gora ekonomska situacija u zemlji zbog izbijanja rata, ali ni brojni štrajkovi nisu mogli zaustaviti pogoršanje situacije i brojna otpuštanja. ${ }^{41}$

35 „Sastanak Samostalne Demokratske strane u Splitu“, ND, br. 105, 6. 5. 1940., 7; F. Jelić Butić, „Banovina Hrvatska (...): Velikosrpski program“, SD, br. 14328, 21. 10. 1990., 24; IstA, „Banovina Hrvatska (...): Izdvajanje iz Hrvatske“, SD, br. 14329, 22. 10. 1990., 27; Ista, „Banovina Hrvatska (...): „Okupiti Srbe“, SD, br. 14330, 23. 10. 1990., 27 ; K. Regan, „Političko djelovanje Krajine u Banovini Hrvatskoj“, 203-205.

37 „Na skupštini Radničke komore u Splitu“, ND, br. 277, 12. 11. 1939., 4.

38 Ivo BANAC, Sa Staljinom protiv Tita. Informbirovski rascjepi u jugoslavenskom komunističkom pokretu, Zagreb 1990., 83-86.

39 „Štrajk obalnih radnika“, $N D$, br. 240, 6. 10. 1939., 6; „Jutros su stupili u štrajk obalno-lučki radnici“, $H G$, br. 234, 6. 10. 1939., 6; „Propao generalni štrajk“, NT, br. 656, 26. 10. 1940., 3. O frakcijskim borbama u Splitu vidi: Sibe Kvesić, Dalmacija u narodnooslobodilačkoj borbi, Zagreb 1960., 21-23.

40

41 „Otpuštanja radnika u Splitu“, NT, br. 659, 15. 11. 1940., 3. Arhivske izvore o svim političkim strankama u Splitu objavila je F. Jelić Butıć, „Banovina Hrvatska (...): Sporazum Cvetković-Maček“, SD, br. 14313, 6. 10. 1990., 43; IstA, „Banovina Hrvatska (...): Povjerljivi izvještaji“, SD, br. 14314, 7. 10. 1990., 25. 


\section{RAT I SIROMAŠTVO}

Ovako ocrtana unutarnjopolitička kretanja odigravala su se u sjeni Drugoga svjetskoga rata, koji je snažno utjecao na zbivanja u čitavoj Jugoslaviji, pa tako i u Splitu. Od 1. rujna 1939. naslovnice lokalnih novina uglavnom su zauzimala ratna zbivanja u Europi, a u gradu se izvode vojne vježbe. ${ }^{42}$ Dok se u govorima brojnih vodećih HSS-ovaca jasno naziralo anglofilstvo, novine su izvještavale o predavanjima britanskih znanstvenika u Splitu, u kojemu je bilo osnovano „Udruženje prijatelja Velike Britanije i Amerike“, ali i „Slavensko kulturno društvo“. ${ }^{43}$ Međutim, sve gora zbivanja u Europi nakon kapitulacije Francuske i lošeg položaja Velike Britanije pogoršale su i položaj Jugoslavije. Zbog rata utišali su se optimistični glasovi koji su isprva izražavali nadu u gospodarski uzlet Dalmacije nakon uspostave Banovine Hrvatske. ${ }^{44}$ Pogoršanje ekonomske situacije jasno se odrazilo u raznim gospodarskim granama i svakodnevici. Strani su turisti dolazili u Split još i u proljeće i ljeto 1940., ali u manjem broju i uglavnom iz podunavskog bazena koji je u to vrijeme bio pošteđen ratnih zbivanja. ${ }^{45}$ Ista je godina bila simbolički važna za Katoličku Crkvu jer se slavilo 1300 godina od doticaja Hrvata s kršćanstvom, ali takve svečanosti, kao i druge priredbe poput karnevala u veljači i rođendana braće Radić u lipnju slavili su se u sve skromnijim uvjetima. ${ }^{46}$ Od kraja kolovoza 1940 . promijenila se politika opskrbe pučanstva, tako da su se viškovi pšenice i brašna mogli prisilno otkupljivati za proizvodnju jednoličnog „narodnog kruha“ ${ }^{47}$ Splitska općina bila je u teškoj financijskoj situaciji, a rast siromaštva bio je vidljiv na svakom koraku. ${ }^{48}$

U takvim okolnostima, putnika koji bi ljeti putovao vlakom iz Zagreba u Split svaki bi put dočekala „strašna i okrutna“ slika na ulazu u Dalmaciju:

Duž pruge, na cesti ili po okolnim strminama poredana od rane zore čekaju gladna zagorska djeca luksuzni vlak iz daljine. Prolaze jutarnji brzi vozovi, a djeca ih s visoko ispruženim rukama prate, vriskajući za njima, trče i mole široko otvorenih oćiju da im se dobaci okrajak kruha ili kakav preostali ostatak jela. Vlak vijuga, a djece je na svakom zaokretu sve veći broj. Treba vidjeti njihove izbezumljene oči i njihove deformirane glavice koje je modelirao glad! Tragična do bola strašna slika naše zaostalosti javlja se kao najrječitiji demanti svih naših velikih fraza i tugaljivih obmana. Ta mala, zaboravljena stvorenja, ta sitna polugola

42 „Markirani napadaj iz zraka na Split“, ND, br. 252, 18. 10. 1939., 6.

43 „Veliki govor dra Jurja Krnjevića u Splitu“, ND, br. 6, 8. 1. 1940., 1; „Psihologija i geografija“, ND, br. 41, 19. 2. 1940., 6; „O engleskom slikarstvu“, ND, br. 79, 4. 4. 1940., 6; „Otvorene prostorije Udruženja prijatelja Vel. Britanije i Amerike“, $N D$, br. 96, 24. 4. 1940., 6; „Slavensko kulturno društvo” u Splitu“, ND, br. 255, 28. 10. $1940 ., 7$.

44 A. JAKIR, Dalmatien zwischen den Weltkriegen, 302-303.

45 „Promet domaćih i stranih turista porastao je pred uskrsne blagdane“, ND, br. 66, 19. 3. 1940., 6; „Na hiljade Splićana i stranaca“, $N D$, br. $159,8.7 .1940 ., 6$

46 „Split u karnevalskom raspoloženju“, ND, br. 29, 5. 2. 1940., 6; „Rođendan braće Radića u Splitu bio je, radi današnjih prilika u svijetu, proslavljen tiho, ali dostojanstveno“, $N D$, br. 139, 14. 6. 1940., 6; „Historijski datum hrvatskog naroda“, $N D$, br. 140, 15. 6. 1940., 7; „Kako su Splićani proveli Božićc, ND, br. 310, 29. 12. 1940., 3; „Split se zabavio...", NT, br. 673, 28. 2. 1941., 3.

47 „Uredba o opskrbi pučanstva protegnuta na Hrvatsku“, ND, br. 205, 30. 8. 1940., 4; „Konferencije o ishrani pučanstva sa područja Banske Ispostave“, ND, br. 225, 23. 9. 1940., 5; „Za bolji kruh“, NT, br. 669, 31. 1. 1941., 3.

48 „Teške financijske prilike splitske općine“, NT, br. 630, 12.4. 1940., 5; „Prosjaci su preplavili Split“, NT, br. 645, 10. 8. 1940., 3; „Zastao rad u splitskoj luci“, NT, br. 645, 10. 8. 1940., 3; „Splitski hoteli zijevaju prazninom“, NT, br. 664, 25. 12. 1940., 13; „Velika nezaposlenost u Splitu“, NT, br. 667, 3. 
tijela, bičevana patnjom i od prvog dana rođenja privikavana na glad i odricanje, ta živa, dvonožna, bosa i gola Hrvatska - naša je budućnost i izvor naše snage! ${ }^{49}$

Autora toga potresnog članka, jednog od brojnih sličnih, ta je slika natjerala da prokune svoje suputnike koji su dobacivanje hrane pretvorili u bezobzirnu igru, da osudi nanovo birokratizirani Zagreb i tamošnje malograđansko činovništvo koje se brine za svoj položaj i ne mari za siromaštvo Dalmacije te da prozove Banovinu Hrvatsku koja se bavi prošlošću, kraljevima narodne dinastije, rukopisima, misalima i teološkim traktatima, živeći u „hiljadugodišnjim iluzijama“ koje nikada nisu prešle uzak krug imućnijih obitelji unutar gradskih zidina dalmatinskih gradova, niti su htjele vidjeti surovu stvarnost u svome zaleđu. ${ }^{50}$

\section{Kulturna I INTELEKTUALnA KRETANJA}

Dok su neki snažno osuđivali poticanje „hiljadugodišnjih iluzija“, za brojne istaknute umjetnike i intelektualce bogata prošlost Splita i Dalmacije bila je stup hrvatskoga kulturnog identiteta i neiscrpan izvor inspiracije, koji je dobio novu dimenziju u Banovini Hrvatskoj. Svi do sada spomenuti problemi - sukobi između hrvatskog i jugoslavenskog identiteta, Hrvata i Srba, politike HSS-a i njegovih protivnika, ratne opasnosti i želje za očuvanjem domovine, inspiracijama bogate prošlosti i tmurne sadašnjosti, bogatstva i siromaštva, Splita i Dalmatinske zagore - zrcalili su se u jednoj osobi koja je svojom veličinom i tijekom postojanja Banovine Hrvatske kulturno najviše izdizala Split, a to je bio Ivan Meštrović. Nije to bilo tako davno kada je kao siromašni „vlaj“ došao u Split, gdje je prepoznat njegov talent, koji je do tada mogao prakticirati samo s pastirskim nožićem na drvu. A u ljeto 1939. godine dovršavala se njegova palača na Mejama, koja je naravno bila bogata, ali ipak uređena „u duhu seljačkom“. I njegovi su kipovi, iako namijenjeni najznačajnijim ljudima tadašnje Europe, crpili inspiracije iz svakodnevice siromašne Dalmatinske zagore. ${ }^{51}$ Ipak se nije zadržavao u Otavicama, gdje mu je bila obitelj, a u Splitu je najviše boravio u svojoj palači, okružen elitnim društvom koje su činili slikari Emanuel Vidović i Jozo Kljaković, karikaturist Anđeo Uvodić i njegov brat Marko te Ivo Tartaglia. Nekoliko puta mjesečno Meštrović bi se s nekima od toga društva (u koje nisu ušli mlađi umjetnici poput slikara Vjekoslava Paraća) sastao u gradu, gdje bi im se znao pridružiti i urednik Novog doba Vinko Brajević, koji je često bio s Tartagliom u nategnutim odnosima..$^{52}$ Dakako, Meštrović je bio i u kontaktu $s$ vodećim političarima u zemlji, ali i poslanicima stranih zemalja te je u pogledu vanjske politike najviše izražavao bojazan od Italije. Unatoč ranijoj povezanosti s kraljem Aleksandrom, tridesetih je godina smatrao da je HSS jedini legitimni predstavnik hrvatskog naroda te je sve više bio privržen Vladku Mačeku. ${ }^{53}$

\footnotetext{
Antun Jurević, „Dvije Dalmacije. Slika s puta“, ND, br. 182, 3. 8. 1940., 7.

Isto.

51 Duško KeČ́nemet, Život Ivana Meštrovića, sv. 2, Zagreb 2009., 81-90.

52 Isto, sv. 1, 527-531; „Splitski umjetnici“, $N D$, br. 107, 8. 5. 1940., 7: „Izmirenje između Dr. Tartaglia i “Novog doba““, NT, br. 671, 14. 2. 1941., 1.

53 D. KečKemet, Život Ivana Meštrovića, sv. 2, 244.
} 
Jedan od najznačajnijih Meštrovićevih umjetničkih projekata u Splitu za vrijeme Banovine Hrvatske je Kaštelet na Mejama. Taj je ruševni ladanjski dvor izgradila početkom 16. stoljeća lokalna trgovačka obitelj Capogrosso, a Meštrović ga je od 1939. otkupio i obnavljao po svojim idejama, koje su često išle protiv konzervatorskih pravila. U obnovljenu crkvicu unutar kompleksa trebala je biti postavljena serija drvenih reljefa iz života Isusa Krista, a u atriju kiparovi gipsani modeli, ali je taj projekt bio dovršen tek nakon rata. ${ }^{54}$

Dok je Meštrović poput patricija ostao udaljen od Splita u idiličnom ambijentu pod Marjanom, jedan je povjesničar umjetnosti ostao $s$,plebejcima“ u gradu i svojom je neumornom djelatnošću postao sveprisutni spiritus movens Splita za vrijeme Banovine Hrvatske. Riječ je o Ljubi Karamanu. Iako je on toliko cijenio Meštrovića da je u zaključku svoga neobjavljenoga pregleda povijesti umjetnosti u Dalmaciji Jahrhundert dalmatinischer Geschichte und Kunstentwicklung jedino njega imenom istaknuo kao najznačajnijeg dalmatinskog umjetnika nakon 1797. godine - kao plod nepotrošene energije dalmatinskog sela koje je dalo svjetski zapažene radove i kao pokazatelja svijetle budućnosti dalmatinske umjetnosti - ipak su njegovi strogi pogledi kao konzervatora Hrvatskog narodnog arheološkog muzeja u Splitu ponekad ukrstili koplja s Meštrovićem. ${ }^{55}$ Tako se Karaman usprotivio Meštrovićevim idejama u obnovi Kašteleta, iako je potonji bio predsjednik društva „Za stari Split“, kojemu je Karaman bio tajnik..$^{56}$ Po tome, ali i po brojnim drugim stvarima vidi se da je Frane Bulić dobio svoga dostojnog nasljednika. Karaman vodi učene strane posjetitelje po Dioklecijanovoj palači, brine se za obnavljanje stare jezgre grada i bori za njezino očuvanje od škodljivih zahvata. ${ }^{57}$ Istom brigom posvećuje se vrijednim starim građevinama u drugim dalmatinskim mjestima, tih godina putuje na konferencije u Italiju i ostaje u kontaktu sa stranim i domaćim učenjacima te objavljuje zapažene radove iz povijesti umjetnosti. ${ }^{58}$

Pored Karamana, u Splitu u to vrijeme djeluje cijeli niz zapaženih intelektualaca. Od povjesničara umjetnosti u splitskim novinama svojim prilozima javlja se još i Cvito Fisković. ${ }^{9}$ Kustos muzeja Hrvatskih starina u Kninu Stjepan Gunjača neumorno otkriva nove nalaze iz „starohrvatskog doba“ u splitskome zaleđu, a povjesničar Lovro Katić, tajnik društva „Bihać, objavljuje radove o starome Solinu. ${ }^{60}$ Nema sumnje da je bavljenje najstarijom hrvat-

54 Isto, 163-168; „Novo Meštrovićevo djelo“, $N D$, br. 106, 7. 5. 1940., 7; „Meštrovićeva skulptura Krista“, ND, br. 182, 3. 8. 1940., 8 .

55 Institut za povijest umjetnosti (dalje: IPU), Arhiv Karaman (dalje: AK), kutija R-40, Jahrhundert dalmatinischer Geschichte und Kunstentwicklung, 85-86.

56 D. KeČKemet, Život Ivana Meštrovića, sv. 2, 243.

57 Isto, 244; „Jedno upozorenje u posljednji čas“, $N D$, br. 215, 11. 9. 1939., 5; „Škola arhitekta Plečnika u Splitu“, $N D$, br. 124, 28. 5. 1940., 6 .

58 Ljubo Karaman, „Starohrvatsko groblje Sv. Staša u Marusincu u Solinu“, ND, br. 319, 25. 12. 1939., 5-6; Ljubo Karaman, „Popravak crkve sv. Ivana u Trogiru“, $N D$, br. 70, 24. 3. 1940., 5; IPU, AK, Osobna dokumentacija Lj. Karaman, „H. Zeiss an Ljubo Karaman, 19. 10. 1940.“; „Akademijin Rad“, ND, br. 91, 18. 4. 1940., 4. Usporedi i Karamanovu korespondenciju s Elzom Kučera: Nacionalna i sveučilišna knjižnica u Zagrebu (NSK), R4771a/b.

59 Vidi npr. Cvito Fisković, „Javni spomenici starijeg doba u Dalmaciji“, ND, br. 319, 25. 12. 1939., 29-30; Cvito Fisković, „'Tamne varijacije’ Antuna Zuppe“, $H G$, br. 295, 25. 12. 1939., 23; Cvito Fisković, „Trifun Bokanić: graditelj zvonika trogirske katedrale“, ND, br. 307, 25. 12. 1940., 29.

60 „Dr. Lovro Katić: Vođa po starohrvatskom Solinu“, ND, br. 255, 21. 10. 1939., 7; „Arheologija“, ND, br. 266, 1. 11. 1939., 7; Stjepan GUnנAČA, „Dolina gornje Cetine u davnoj prošlosti“, ND, br. 319, 25. 12. 1939., 43-44. 
skom poviješću bilo od presudne važnosti u kreiranju imaginarija i legitimaciji mlade Banovine Hrvatske pa ne čudi vijest da je sam ban Šubašić bio uključen u odobravanje financijskih sredstava za Gunjačina iskopavanja, a Mate Ujević zvao neke od ovih intelektualaca (poput Karamana i Fiskovića) da pišu članke za Hrvatsku enciklopediju. ${ }^{61}$

U Splitu svoju karijeru kao gimnazijski profesor počinje lingvist Miroslav Kravar, a istim se zanimanjem bavi prirodoslovac i popularizator znanosti Ćiro Gamulin. ${ }^{62}$ Povjesničar i publicist Boško Desnica, Urošev brat koji je bio povezan $s$ velikosrpskim krugovima u splitskome zaleđu, objavljivao je u ovo vrijeme svoje uratke u Novom dobu..$^{63} \mathrm{Ne}$ smije se zaboraviti ni da su tada u Splitu živjeli Vladan Desnica i Vladimir Rismondo, iako je vrijeme Banovine Hrvatske za njih proteklo u tihome radu. Kroz tisak se među širom kulturnom javnošću ši-

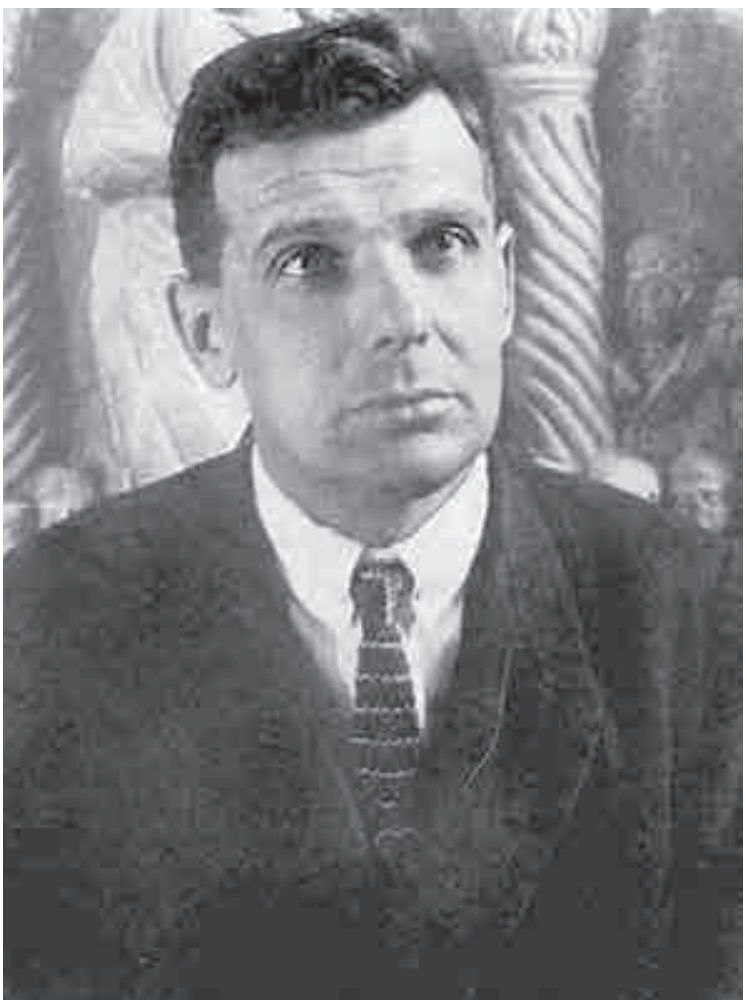

Sl. 3. Ljubo Karaman - dostojan nasljednik Frane Bulića re imena tada novijih ili manje poznatih književnika, poput Slavka Kolara i ustaškog ideologa Mile Budaka, kojima se posvetio povjesničar književnosti Vice Zaninović. ${ }^{64}$ Glavna prilika da splitski intelektualci podastru svoje radove sugrađanima bili su božićni i uskršnji brojevi Hrvatskog glasnika i Novog doba, pri čemu su brojni sudjelovali u oba lista, ali je drugi ipak okupljao širi krug suradnika.

Međutim, i pored nabrojanih umjetnika i intelektualaca, kojima bi se zasigurno mogla dodati i druga imena, stalne su bile pritužbe na siromaštvo kulturnog života grada, kao i na probleme u vezi kulturnih institucija poput Gradske biblioteke i Gradskog arhiva. ${ }^{65}$ Možda

$\overline{61}$ „Starohrvatske iskopine“, $N D$, br. 28, 3. 2. 1940., 8; Job PAAL, „Tamo, gdje su vladali veliki knezovi“, ND, br. 20, 17. 2. 1940., 9-10; „Nova starohrvatska otkrića“, ND, br. 363, 20. 12. 1940., 5; IPU, AK, Osobna dokumentacija Lj. Karaman, „Mate Ujević Ljubi Karamanu 6. 3. 1941.“

62 Ćiro Gamulin, „Macocha - čudo podzemlja“, ND, br. 319, 25. 12. 1939., 47; Ćiro Gamulin, „I životinje se igraju“, ND, br. 307, 25. 12. 1940., 31; Miroslav Kravar, „Pjesnik Juvenal o dekadenci rimskog društva“, ND, br. $307,25$. 12. 1940., 33.

63 K. Regan, „Političko djelovanje Krajine u Banovini Hrvatskoj“, 205; Boško Desnica, „Dalmacija u memoarima Carla Gozzi“, ND, br. 319, 25. 12. 1939., 15; Boško Desnica, „Arhivski pabirci“, ND, br. 70, 24. 3. 1940., 7; Boško Desnica, „Zidanje Opuzena“, ND, br. 307, 25. 12. 1940., 15.

64 Vice Zaninović, „Slavko Kolar - Mile Budak“, ND, br. 6, 7. 1. 1939., 9; Vinko Nikolić, „Idejno značenje Budakova romana San o sreći“, ND, br. 307, 25. 12. 1940., 25.

65 „Sjajan uspjeh prvog koncerta 'Hrvatske Filharmonije u Splitu'“, ND, br. 69, 22. 3. 1940., 7; „Dva kulturna problema u Splitu“, NL, br. 16, 25. 4. 1940., 8. 
i najveće napore da se takvo stanje popravi tijekom čitavoga kratkoga života Banovine Hrvatske poduzima skladatelj Ivo Tijardović, s kojim je bilo blisko povezano pitanje Hrvatskoga narodnog kazališta (HNK). Pitanje stalnoga kazališta, koje je Split izgubio desetak godina prije uspostave Banovine Hrvatske, postalo je goruće nakon Sporazuma. ${ }^{66}$ Zbog toga je već u listopadu 1939. osnovano stalno kazalište na čije je čelo postavljen Tijardović, ali je bilo potrebno čekati da se to kazalište organizira, što je bilo otežano zbog nedostatka sredstava, neuređenosti prostora i sličnih teškoća. Stara kazališna zgrada je nakon financijske pomoći iz Zagreba obnovljena i 5. prosinca 1940. svečano je otvoren HNK s Tijardovićem kao prvim intendantom. ${ }^{67}$ Iako toj svečanosti nisu prisustvovali Maček, Šubašić ni istaknutiji prvaci HSS-a, pa čak niti splitsko-makarski biskup Kvirin Klement Bonifačić, otvaranje je bilo prepuno velikih riječi, a niti datum - 22. obljetnica prosinačkih žrtava - vjerojatno nije slučajno odabran. Tako je povjerenik Ispostave Banske vlasti Mate Bulić čin otvorenja HNK povezao s dovršenjem stare zgrade 1893. nakon rušenja „tuđinske prevlasti“ pod Gajom Bulatom. Split je nazvao kolijevkom hrvatske državne misli, a uspješno otvaranje HNK uz pomoć Zagreba povezao je sa stapanjem dva grada i uopće „nacionalnokulturnoga ujedinjenja Hrvata“. U svečanoj atmosferi slične govore održali su gradonačelnik Josip Brkić, Tijardović i drugi uzvanici, završavajući ih poklicima Šubašiću i Mačeku. ${ }^{68}$

Split se razvijao i na drugim poljima neposredno prije Drugoga svjetskoga rata. Neki od značajnijih pothvata u tome razdoblju bili su dovršenje zgrada za Klasičnu i Mušku realnu gimnaziju, zatim za Banovinsku palaču koja je izazivala vječite prijepore, tekla je izgradnja kupališne zgrade na Bačvicama, bolnice na Firulama i pravoslavne crkve sv. Save, a Dom umjetnosti i Sudska palača bili su u planu. ${ }^{69}$ Posebne je rezultate dalo društvo „Marjan“. Bavilo se pošumljavanjem istoimenog brdašca, što je dobrim dijelom promijenilo sliku $\operatorname{grada}^{70}$

$\overline{66}$ „Subvencija za stalno kazalište u Splitu“, ND, br. 30, 4. 2. 1939., 9.

67 „Splitsko kazališno društvo“, $N D$, br. 257, 23. 10. 1939., 3; „Treba li u Splitu graditi novo kazalište?“, ND, br. 20, 25. 1. 1940., 5; „Splitsko kazalište će se potpuno urediti do septembra ove godine i to na najmoderniji način“, $N D$, br. 52, 2. 3. 1940., 7; „Problem Splitskog kazališta“, ND, br. 83, 9. 4. 1940., 6; „Razgovor s direktorom splitske Drame“, ND, br. 89, 16. 4. 1940., 6; „G. Tijardović o splitskom kazalištu“, ND, br. 96, 24. 4. 1940., 6; „Splitski teatar g. Ive Tijardovića“, $N L$, br. 17, 2. 5. 1940., 6; „Za Splitsko Kazalište 2 milijuna za uređenje zgrade“, ND, br. $112,14$. 5. 1940., 6; „Repertoar Hrvatskog narodnog kazališta u Splitu: razgovor s dramaturgom g. prof. Vojmilom Rabadanom“, $N D$, br. 206, 31. 8. 1940., 5 .

68 „Svečano otvorenje Hrvatskog narodnog kazališta u Splitu“, ND, br. 289, 6. 12. 1940., 6; „Svečano otvorenje kazališta 5 decembra 1940“, NL, br. 49, 12. 12. 1940., 1.

69 „Juče su otvorene gimnazijske zgrade“, ND, br. 219, 16. 9. 1940., 6; „Nova banovinska palača u Splitu i gradnja Paviljona za likovnu umjetnost“, $N D$, br. 194, 17. 8. 1940., 9; „Odobren kredit za dovršenje splitske bolnice“, $N D$, br. 240, 10. 10. 1940., 5; „Izgradnja nove splitske bolnice“, ND, br. 259, 1. 11. 1940., 6; „Sudska palača u Splitu će se graditi“, $N D$, br. 67, 9. 3. 1941., 3; Ante KAšper, „Nova banovinska palača u Splitu i gradnja Paviljona za likovnu umjetnost“, ND, br. 81, 23. 3. 1941., 3. Detaljnije o tome u: Stanko Piplović, „Urbani razvitak Splita između dva rata", Vladan Desnica i Split 1920. - 1945. Zbornik radova sa znanstvenog skupa Desničini susreti 2014. (ur. Drago Roksandić i Ivana Cvijović Javorina), Zagreb 2015., 157-180. 


\section{POSLJEDNJI MJESECI PRIJE IZBIJANJA RATA}

Posljednji su mjeseci prije izbijanja Travanjskog rata u Splitu bili obilježeni dodatnim pogoršanjem ekonomskog stanja. Racionalizacija potrošnje hrane dovela je do prijevara proizvođača koje su ponekad bile opasne po zdravlje, što je izazivalo stalne proteste među građanstvom. ${ }^{71}$ Ekonomske teškoće jasno su se vidjele i početkom veljače 1941., kada je potpuno dovršen Iseljenički muzej u Splitu, osnovan kako bi se, među ostalim, Banovina Hrvatska jače povezala s iseljeništvom. Naime, na svečanosti otvorenja priznalo se da je iseljavanje još uvijek jedan od glavnih socijalnih problema u državi. ${ }^{72}$ Radništvo je i dalje bilo pauperizirano, a nakon ukidanja URS-a brigu nad radnicima koji su pripadali tom sindikatu, preuzeo je HSS-ov Hrvatski radnički savez (HRS), koji je imao snažno antikomunističko usmjerenje. ${ }^{73}$

Za intelektualnu elitu grada glavni su se događaji odigrali početkom ožujka, kada je iz tiska izašao prvi svezak Hrvatske enciklopedije i kada je otvorena izložba novih Vidovićevih radova. Prisustvovali su joj, među ostalima, Kljaković, Karaman i Parać. ${ }^{74}$ Predstave koje je priređivao HNK bile su pozitivno primljene, ali je ta institucija doživjela svojevrsni udarac kada je Tijardović premješten iz Splita u Osijek. ${ }^{75}$

U političkom pogledu, stanje u Splitu kretalo se u istome smjeru koji je bio utaban prošlih godina, ali je sve primjetnije bilo političko zatišje i očekivanje daljnjeg razvoja događaja. HSS je i dalje bio obilježen unutarstranačkim sukobima, a njegov je Hrvatski glasnik prestao izlaziti već u prosincu 1940. godine. Umjesto njega pokrenut je tjednik Dalmatinska Hrvatska. U njemu su se mogli pročitati sve radikalniji nacionalistički stavovi. ${ }^{76}$ SDS je nastavio podržavati koalicijskog partnera, a za pogrešne stvari koje su nastale primjenom Sporazuma vodstvo stranke je naglašavalo da će se ispraviti samo slogom naroda. ${ }^{77}$

Od državnog udara 27. ožujka 1941. događaji u Splitu počinju se odvijati velikom brzinom. Meštrović je tada bio u Splitu, gdje mu je društvo pravio urednik Nove Evrope Milan Ćurčin:

Sjedili smo obično do kasno uvečer, razgovarali i pratili vijesti. Najednom smo, poslije puča, čuli govor srpskog patrijarhe. To je bio govor u kojem je bio sažet sav šovinizam srpstva i pravoslavlja, koje da je jedino održalo „zavjetnu misao“, jedino koje je stvorilo državu i

71 „Kažnjeno više pekara radi loše izrade kruha“, $N D$, br. 29, 30. 1. 1941., 6; „Potrošačke iskaznice za grad Split“, $N D$, br. 39, 9. 2. 1941., 6; „Kruh naš svagdašnji'“, ND, br. 41, 11. 2. 1941., 6; „Spriječite opasnost za živote djece i odraslih!“, ND, br. 74, 16. 3. 1941., 6.

72 „Otvorenje Iseljeničkog muzeja u Splitu“, $N D$, br. 38, 8. 2. 1941., 6.

73 „Godišnja skupština podružnice HRS-a u Splitu“, ND, br. 47, 17. 2. 1941., 5; „Svi sklopljeni kolektivni ugovori od strane URS-a ostaju i dalje na snazi“, ND, br. 55, 25. 2. 1941., 6.

74 „Izašla je 'Hrvatska Enciklopedija'“, $N D$, br. 60, 2. 3. 1941., 4; „Svečano otvorenje Vidovićeve izložbe“, $N D$, br. 65, 7. 3. 1941., 6 .

75 „Odlazak g. Tijardovića“, NT, br. 676, 21. 3. 1941., 5.

76 „Prestao izlaziti 'Hrvat. Glasnik'“, NT, br. 663, 13. 12. 1940., 3; „Novi organ HSS“, NT, br. 667, 17. 1. 1941., 3; „Izjava mjesne organizacije HSS na Klisu“, ND, br. 39, 9. 2. 1941., 4; „Burna skupština ‘Gospodar. Sloge’ u Splitu“, ND, br. 60, 2. 3. 1941., 7; A. JAKIR, Dalmatien zwischen den Weltkriegen, 441.

77 „Okružna konferencija Samostalne Demokratske Stranke“, ND, br. 47, 17. 2. 1941., 4. 
jedino koje će braniti i obraniti. Saslušavši taj govor, svi smo se zagledali bez riječi. Ja sam i nehotice prvi prozborio:

- Ovo je početak propasti, njezin prvi čin. Ovaj i ovakav govor ubojitije je oružje od svih njemačkih topova i tenkova; njega će slijediti rasulo Jugoslavije i tragedija njezinih naroda. ${ }^{78}$

Ako je Meštrović uistinu tako i doživio tadašnje događaje, tonovi prisutni u splitskome tisku bili su drugačiji. Nakon što je Petar II. Karađorđević preuzeo vlast, u gradu se održavala svečana povorka vojske, pri čemu je vojnike pozdravljala gomila znatiželjnih građana, a održani su i svečani obredi u čast novoga kralja. ${ }^{79}$ Maček je prihvatio potpredsjedništvo u novoj vladi, izrazivši nadu u mir i nastavak suradnje s Beogradom. ${ }^{80}$

Ipak, nije trebalo proći dugo vremena da dezorijentacija ključnih ljudi u državi postane jasno vidljiva. Isprva je uslijedilo političko rasipanje pa je tako JRZ nestala s političke scene, a ilegalne organizacije poput Komunističke partije postajale su sve aktivnijima. U Splitu se jedino Anđelinović, unatoč nedjelotvornosti svoje politike, još uvijek uzaludno pozivao na jugoslavenski nacionalizam protiv radikalnih nacionalista. ${ }^{81}$

Dok je Jugoslavija bila u takvome stanju, sile Osovine zgrabile su priliku i upotrijebile svoju iskušanu taktiku optuživši je da zlostavlja njemačku i talijansku manjinu. Početkom travnja brojni su talijanski državljani brzo napustili Split, što je bio jasan znak da se uvijek budna i agresivna fašistička sila s druge strane Jadranskog mora napokon sprema uzeti vječni predmet svojih želja - Dalmaciju. ${ }^{82} \mathrm{~S}$ tim je strahom u Splitu završilo međuratno razdoblje, upravo kako je i počelo gotovo četvrt stoljeća prije.

\section{ZAKLJUČAK}

Za vrijeme Banovine Hrvatske Split je vrvio bogatim političkim, kulturnim i intelektualnim životom. Nove političke okolnosti nametnule su nove teme, probleme i drugačiji odnos snaga među tadašnjim političkim strankama. HSS je u Splitu bio neprijeporni politički vladar, ali se još nije bio učvrstio u svojoj novoj ulozi, što je bilo jasno vidljivo u brojnim čimbenicima, poput stalnih sukoba unutar stranke. Jedina jača politička opozicija u gradu bio je JNS, koji je, doduše, stalno gubio svoju snagu i političku privlačnost. Za obje strane nedavna je prošlost predstavljala kako izvor legitimacije tako i izazov koji se nastojao eliminirati posebnom politikom sjećanja. Odmetnute frakcije JRZ-a i JNS-a u splitskome su zaleđu očitovale velikosrpske tendencije, što je također imalo odjeka u političkome životu grada. Unutar redova Komunističke partije Jugoslavije različite ocjene Sporazuma Cvetko-

\footnotetext{
78 Ivan Mešrrović, Uspomene na političke ljude i dogadaje, Zagreb 1993., 266-267.

79 „Svečane povorke vojske u Splitu“, $N D$, br. 86, 28. 3. 1941., 6; „Svečana blagodarenja u Splitu“, ND, br. 89, 31.3. 1941., 5 .

80 „Maček prihvatio podpredsjedništvo vlade“, ND, br. 92, 3. 4. 1941., 1.

81 „JRZ nestala“, NT, br. 678, 3. 4. 1940., 2; S. Kvesić, Dalmacija u narodnooslobodilačkoj borbi, 49-51; A. JAKIR, Dalmatien zwischen den Weltkriegen, 442-443.

82 „Strani državljani iz Splita“, ND, br. 91, 2. 4. 1941., 6; „Strana propaganda zavarava svoju javnost“, ND, br. 93 , 4. 4. 1941., 1.
} 
vić - Maček dovele su do novih frakcijskih borbi. Sve veće ekonomske teškoće uvjetovane izbijanjem Drugoga svjetskoga rata u Europi splitski su komunisti znali dobro iskoristiti za širenje svoga utjecaja. Posljednji su mjeseci prije Travanjskoga rata u gradu obilježeni sve snažnijim ekonomskim propadanjem i političkim zatišjem, koje će biti naglo prekinuto nakon državnog udara u Beogradu 27. ožujka 1941. godine.

Uspostava Banovine Hrvatske utjecala je i na splitska kulturna i intelektualna kretanja. Obnovljen je HNK, na čijem je čelu bio Ivo Tijardović, a u gradu djeluju Ivan Meštrović, Emanuel Vidović, Ljubo Karaman, Stjepan Gunjača i brojni drugi umjetnici i intelektualci.

\section{Contributions to the Political, Cultural and Intellectual History of Split in the Time of the Banovina of Croatia (i939-I94I)}

The Cvetković - Maček Agreement from August 1939 established the autonomous Banovina of Croatia within the Kingdom of Yugoslavia. The new political circumstances placed Split in a different position, which was manifest in the stronger interest of the leadership of the Croatian Peasant Party in the city, as it used different strategies seeking to strengthen the city's connection to the rest of the Banovina of Croatia. The Agreement created a different balance of power among the political parties that had a measurable presence in the city, as well as the balance of power within them. The Croatian Peasant Party reached its political peak, but it also found it increasingly difficult to maintain discipline within its ranks. The Yugoslav National Party split into two groups, and the more moderate circle operated in Split, following the federalist policy of the party centre in Belgrade. The two parties clashed primarily because the former had a Croatian national orientation, while the latter had the Yugoslav orientation, which was clearly evidenced by their differing views on state organization and by their different politics of memory. At the same time, the renegade factions of the Yugoslav National Party and the Yugoslav Radical Union supported Great-Serbian tendencies in the Split hinterland. These domestic political developments were happening in the shadow of the outbreak of World War II in Europe, which caused economic difficulties in Split, which turned out to create the fertile ground for the activity of the Communist Party of Yugoslavia. Using a trade union organization, the Communist Party staged several protest rallies and strikes. The described political constellation impacted the work of Split artists, intellectuals and cultural workers. Among them one should first mention the sculptor Ivan Meštrović, then the painter Emanuel Vidović, art historian Ljubo Karaman, historians Stjepan Gunjača and Lovro Katić, composer Ivo Tijardović, and many others. In spite of the difficult circumstances, Split was showing signs of development, particularly in terms of the founding of new associations and cultural institutions, and construction of new buildings.

Key words: Split, Banovina of Croatia, Kingdom of Yugoslavia, political history, cultural history, intellectuals 


\section{$\cos$}

\section{Izvori i literatura}

\section{Neobjavljeni izvori}

Institut za povijest umjetnosti, Arhiv Karaman

Nacionalna i sveučilišna knjižnica u Zagrebu, Korespondencija Ljubo Karaman - Elza Kučera, R $4771 \mathrm{a} / \mathrm{b}$

\section{Periodika}

Hrvatski glasnik (Split)

Narodni list (Split)

Nova tribuna (Šibenik)

Novo doba (Split)

\section{Objavljeni izvori i literatura}

Dragan BAKıć, „Prilog za biografiju: politička karijera Uroša Desnice u vremenu iskušenja (19191941)“, Vladan Desnica i Split 1920. - 1945. Zbornik radova sa znanstvenog skupa Desničini susreti 2014. (ur. Drago Roksandić i Ivana Cvijović Javorina), Zagreb 2015., 235-257.

Ivo Banac, Sa Staljinom protiv Tita. Informbirovski rascjepi u jugoslavenskom komunističkom pokretu, Zagreb 1990.

Aleksandar Jakir, Dalmatien zwischen den Weltkriegen. Agrarische und urbane Lebenswelt und das Scheitern der jugoslawischen Integration, München 1999.

Zdravka Jelaska Marijan, Grad i ljudi: Split 1918.-1941., Zagreb 2009.

Fikreta Jelić Butić, „Banovina Hrvatska. Političke prilike na području Ispostave banske vlasti u Splitu 1939.-40. godine“, Slobodna Dalmacija (Split), br. 14313, 6. 10. 1990., 43; br. $14314,7$. 10., 25; br. 14315, 8. 10., 25; br. 14316, 9. 10., 27; br. 14317, 10. 10., 23; br. 14318, 11. 10., 30; br. $14319,12.10 ., 23$; br. $14320,13.10 ., 43$; br. 14321,14 . 10., 25; br. 14322, 15. 10., 24; br. 14323, 16. 10., 27; br. 14324, 17. 10., 30; br. 14325, 18. 10., 30; br. 14326, 19. 10., 23; br. 14327, 20. 10., 41; br. 14328, 21. 10., 24; br. 14329, 22. 10., 27 i br. 14330, 23. 10., 27.

Duško KečKemet, Život Ivana Meštrovića, 2 sv., Zagreb 2009.

Sibe Kvesić, Dalmacija u narodnooslobodilačkoj borbi, Zagreb 1960.

Stjepan Matković, „Senatori iz Splita: suočavanje s krizom Jugoslavije i jugoslavenstva“, Vladan Desnica i Split 1920. - 1945. Zbornik radova sa znanstvenog skupa Desničini susreti 2014. (ur. Drago Roksandić i Ivana Cvijović Javorina), Zagreb 2015., 307-330.

Ivan MešTrović, Uspomene na političke ljude i dogadaje, Zagreb 1993.

Stanko Piplović, „Urbani razvitak Splita između dva rata“, Vladan Desnica i Split 1920. - 1945. Zbornik radova sa znanstvenog skupa Desničini susreti 2014. (ur. Drago Roksandić i Ivana Cvijović Javorina), Zagreb 2015., 157-180.

Krešimir REgAN, „Djelovanje Jugoslavenske nacionalne stranke u Banovini Hrvatskoj 1939-1941.“, Kolo, 17/2007., br. 4, 108-125.

Krešimir Regan, „Djelovanje Jugoslavenske radikalne zajednice u doba Banovine Hrvatske (1939_ 1941)“, Studia lexicographica, 1/2007., br. 1, 217-254.

Krešimir Regan, „Političko djelovanje Krajine u Banovini Hrvatskoj“, Historijski zbornik, 60/2007., 179-213.

Drago Roksandić, „Dr. Uroš Desnica 1918.-1921.: životopisne nedoumice na raskrižju epoha“, Splatumque dedit ortum. Zbornik povodom desete godišnjice Odsjeka za povijest Filozofskog fakulteta u Splitu (ur. Ivan Basić i Marko Rimac), Split 2014., 499-511. 